\title{
Review
}

\section{On the Pleotropic Actions of Mineralocorticoids}

\author{
Florian Lang \\ Department of Physiology, Eberhard Karls University of Tübingen, Tübingen, Germany
}

\section{Key Words}

Mineralocorticoids - Electrolyte transport - Salt appetite .

Blood pressure - Glucose - Fibrosis - Calcification - Blood platelets

\begin{abstract}
Classical effects of mineralocorticoids include stimulation of $\mathrm{Na}^{+}$reabsorption and $\mathrm{K}^{+}$secretion in the kidney and other epithelia including colon and several glands. Moreover, mineralocorticoids enhance the excretion of $\mathrm{Mg}^{2+}$ and renal tubular $\mathrm{H}^{+}$secretion. The renal salt retention following mineralocorticoid excess leads to extracellular volume expansion and hypertension. The increase of blood pressure following mineralocorticoid excess is, however, not only the result of volume expansion but may result from stiff endothelial cell syndrome impairing the release of vasodilating nitric oxide. Beyond that, mineralocorticoids are involved in the regulation of a wide variety of further functions, including cardiac fibrosis, platelet activation, neuronal function and survival, inflammation as well as vascular and tissue fibrosis and calcification. Those functions are briefly discussed in this short introduction to the special issue. Beyond that, further contributions of this special issue amplify on mineralocorticoidinduced sodium appetite and renal salt retention, the role of
\end{abstract}

mineralocorticoids in the regulation of acid-base balance, the involvement of aldosterone and its receptors in major depression, the mineralocorticoid stimulation of inflammation and tissue fibrosis and the effect of aldosterone on osteoinductive signaling and vascular calcification. Clearly, still much is to be learned about the various ramifications of mineralocorticoid-sensitive physiology and pathophysiology.

(C) 2014 S. Karger AG, Basel

\section{Introduction}

Mineralocorticoids are key hormones regulating extracellular volume homeostasis $[1,2]$. Their release is upregulated in extracellular volume depletion, they enhance salt intake by upregulating salt appetite $[3,4]$ and they decrease renal salt loss by stimulating salt reabsorption in the aldosterone-sensitive nephron segments $[1,2]$. Moreover, mineralocorticoids curtail salt loss by stimulating salt (re)absorption in colon $[5,6]$, sweat glands and salivary glands [6]. At least in part due to extracellular volume expansion, mineralocorticoids enhance cardiac output and blood pressure $[7,8]$. However, the mineralocorticoid receptor [9-11] is expressed in a wide variety of tissues [10]. The mineralocorticoid receptor binds aldo-

\section{KARGER}

E-Mail karger@karger.com

www.karger.com/nep
(C) 2014 S. Karger AG, Basel

$1660-2137 / 14 / 1282-0001 \$ 39.50 / 0$
Prof. Florian Lang

Department of Physiology, Eberhard Karls University of Tübingen Gmelinstrasse 5

DE-72076 Tübingen (Germany)

E-Mail florian.lang@uni-tuebingen.de 
sterone, cortisol and corticosterone with similar affinity $[10,12]$ but the inactivation of glucocorticoids by $11 \beta$-hydroxysteroid dehydrogenase 2 (HSD2) in aldosterone-target cells confers some aldosterone specificity in those cells $[10,12,13]$. More recent research revealed further functions of mineralocorticoids, which are seemingly unrelated to extracellular volume regulation. This brief overview will address some of those functions. Moreover, several of those functions are amplified in separate short reviews of this special issue.

\section{Effects of Mineralocorticoids}

Mineralocorticoids are powerful regulators of renal tubular salt transport $[1,2]$. They upregulate the epithelial $\mathrm{Na}^{+}$channels, the apical $\mathrm{K}^{+}$channels and the $\mathrm{Na}^{+} / \mathrm{K}^{+}$ ATPase and thus stimulate renal tubular $\mathrm{Na}^{+}$reabsorption and $\mathrm{K}^{+}$secretion in the aldosterone-sensitive nephron segments $[1,2]$. The aldosterone-induced renal $\mathrm{Na}^{+}$ retention in the distal nephron leads to extracellular volume expansion, which inhibits $\mathrm{Na}^{+}$reabsorption in the proximal tubule and thick ascending limb resulting in reduced $\mathrm{Ca}^{2+}$ and $\mathrm{Mg}^{2+}$ reabsorption in those nephron segments $[14,15]$. As a result, aldosterone leads to magnesuria and calciuria $[14,15]$. Mineralocorticoids further stimulate renal tubular $\mathrm{H}^{+}$secretion and thus generate alkalosis [16-18]. Aldosterone modifies renal acid excretion in part by upregulating both $\mathrm{H}^{+}$pumps and $\mathrm{Cl}^{-} / \mathrm{HCO}_{3}{ }^{-}$exchanger pendrin [18]. Mineralocorticoids upregulate pendrin in a variety of further tissues [19]. The functional significance of mineralocorticoid-sensitive pendrin regulation in those tissues remained elusive.

Mineralocorticoids further enhance salt appetite [2,4] and thus foster salt intake, as amplified in separate reviews of this special issue $[20,21]$. Enhanced salt intake and renal salt retention lead to extracellular volume expansion with increase of blood pressure $[7,8,22]$. The effect of mineralocorticoids on blood pressure does, however, not depend on the effect of mineralocorticoids on the distal nephron [23] but is attributed in part to vascular inflammation [24, 25], to enhanced endothelial stiffness, which compromises the release of nitric oxide [2630 ] and direct effects of the mineralocorticoid receptor in vascular smooth muscle [31]. Besides leading to systemic hypertension, mineralocorticoids could foster pulmonary hypertension [32].

Moreover, mineralocorticoids increase vascular stiffness $[33,34]$ and vascular as well as soft tissue calcifica- tion $[25,35,36]$, as amplified in a separate contribution to this special issue [37]. Mineralocorticoids influence tissue calcification in part by downregulation of klotho [38, 39].

Mineralocorticoids further stimulate cardiac and renal fibrosis [33, 40-56], as discussed in a further contribution to this special issue [57].

The increase of blood pressure following aldosterone action affects the heart, which is further affected by direct effects of mineralocorticoid receptors on cardiac function, electrical conduction, oxidative stress, inflammation and fibrosis $[43,58,59]$.

Mineralocorticoid receptors are further involved in the regulation of adipogenesis as well as adipose tissue expansion and may contribute to insulin resistance and obesity [60-63]. Mineralocorticoids affect neuronal function and survival $[3,64-67]$ as amplified in a separate review of this special issue [21].

Mineralocorticoids upregulate the pore-forming $\mathrm{Ca}^{2+}$ channel protein Orail [68] and thus increase the $\mathrm{Ca}^{2+}$ concentration [69] in blood platelets. Activation of Orai1 contributes to store-operated calcium entry (SOCE) [70, 71], thus leading to platelet activation [72-74], cytoskeletal reorganization with respective shape changes [75] and cell membrane scrambling with phosphatidylserine translocation to the outer platelet membrane surface [7680]. Phosphatidylserine at the platelet surface enhances in turn thrombin formation and platelet procoagulant activity $[77-79,81]$. Moreover, increased $\mathrm{Ca}^{2+}$ concentration triggers platelet degranulation, integrin $\alpha_{\mathrm{II}} \beta_{3}$ activation and adhesion of platelets [72]. Orail protein abundance and thus $\mathrm{Ca}^{2+}$ entry are upregulated by the serum- and glucocorticoid-inducible kinase isoform SGK1 [82, 83], a kinase strongly upregulated by mineralocorticoids [84]. Orail is further upregulated by the isoform SGK3 [85]. SGK1 upregulates in megakaryocytes the transcription factor NF- $\kappa \mathrm{B}$, which in turn stimulates Orail expression [82]. Mineralocorticoids thus enhance the sensitivity of platelets to activators and mineralocorticoid excess is thus expected to foster thrombosis and vascular occlusive disease [82]. On the other hand, specific activation of the endothelial mineralocorticoid receptor may counteract thrombosis [86].

\section{Mechanisms Involved in Mineralocorticoid Effects}

Mineralocorticoids are, at least partially, effective by binding to the mineralocorticoid receptor, which acts as a ligand-dependent transcription factor regulating gene 
expression $[9,34,36,46,48,87-89]$. The receptor is similar to the glucocorticoid receptor and may be activated by glucocorticoids [90]. Activation of the mineralocorticoid receptor upregulates a wide variety genes involved in transport such as channels, carriers and transport-regulating signaling molecules including the serum- and glucocorticoid-inducible kinase SGK1 [91, 92].

Mineralocorticoid receptor activation further triggers inflammation in part due to stimulation of reactive oxygen species generation by nicotinamide adenine dinucleotide phosphate (NADPH) oxidase and mitochondria [43]. In the heart, activation of mineralocorticoid receptors leads to activation of the $\mathrm{Na}^{+} / \mathrm{H}^{+}$exchanger NHE-1 with subsequent increase of cytosolic $\mathrm{Na}^{+}$and $\mathrm{Ca}^{2+}$ entry through reversal of the $\mathrm{Na}^{+} / \mathrm{Ca}^{2+}$ exchanger [93]. Notably NHE1 is upregulated by oxidative stress [93] and SGK1 $[94,95]$.

The effects of mineralocorticoids are augmented by Ras-related C3 botulinum toxin substrate 1 (Rac1), a Rho-family small GTPase [96].

Besides their effect on gene expression, mineralocorticoids could exert nongenomic effects $[3,33,56,66,67$, 97-104], which are, at least partially, mediated by angiotensin-II receptor and $\mathrm{G}$ protein-coupled receptor 30 [43]. Signaling involved in nongenomic mineralocorticoid action includes stimulation of phosphatidylinositide-3-kinase (PI3K) [105, 106].

As apparent from blood platelets [68], mineralocorticoids may further influence protein translation, which is regulated by the translation initiation factors elF-4E and elF- $2 \alpha$ eIF-4E $[107,108]$ as well as the inhibitory $4 \mathrm{E}$-binding protein $4 \mathrm{E}-\mathrm{BP} 1$ [107]. 4E-BP1 is phosphorylated by PI3K [109] and subsequently binds eIF-4E, thus inhibiting translation [109]. Mineralocorticoids activate PI3K leading to redistribution of the initiation factors to the proximity of mRNA [107]. Initiation of translation requires both actin polymerization and PI3K activation [110].

\section{Pathophysiology of Mineralocorticoid Excess}

Excessive mineralocorticoid action is associated with enhanced risk of vascular disease, such as hypertension, heart failure, cardiac electrical remodeling, atrial fibrillation, atherosclerosis and fibrosis $[33,58,111-116]$. The cardiovascular disease in mineralocorticoid excess is the result of extracellular volume expansion with hypertension $[7,8,41]$, endothelial stiffness with compromised NO release [26-30], cardiovascular inflammation and fibrosis $[43,57,117,118]$ as well as calcification with enhanced vascular stiffness [35-37]. Moreover, vascular events may result from enhanced $\mathrm{Ca}^{2+}$ entry into blood platelets [69] with enhanced degranulation, aggregation and adhesion [68] and eventually acute thrombotic occlusion following atherosclerotic plaque rupture $[82,119]$ and ischemic cardiovascular events such as myocardial infarction or ischemic stroke [120]. In the kidney, excessive mineralocorticoid action leads to renal inflammation, fibrosis, podocyte injury, and mesangial cell proliferation [121]. The pathophysiological consequences of mineralocorticoid action could be reversed by mineralocorticoid receptor antagonists $[58,63,116,122-140]$. The therapeutic potential of mineralocorticoid receptor antagonists is thus not only confined to their diuretic action, but involves prevention of tissue fibrosis, vascular calcification and vascular occlusive disease.

\section{Disclosure Statement}

The author has no conflicts of interest to disclose.

\section{References}

1 Briet M, Schiffrin EL: Aldosterone: effects on the kidney and cardiovascular system. Nat Rev Nephrol 2010;6:261-273.

$\checkmark 2$ Pearce D, Bhargava A, Cole TJ: Aldosterone: its receptor, target genes, and actions. Vitam Horm 2003;66:29-76.

3 Sakai RR, McEwen BS, Fluharty SJ, Ma LY: The amygdala: site of genomic and nongenomic arousal of aldosterone-induced sodium intake. Kidney Int 2000;57:1337-1345.
4 Vallon V, Huang DY, Grahammer F, Wyatt AW, Osswald H, Wulff P, Kuhl D, Lang F: SGK1 as a determinant of kidney function and salt intake in response to mineralocorticoid excess. Am J Physiol Regul Integr Comp Physiol 2005;289:R395-R401.

$\checkmark 5$ Harvey BJ, Alzamora R, Stubbs AK, Irnaten M, McEneaney V, Thomas W: Rapid responses to aldosterone in the kidney and colon. J Steroid Biochem Mol Biol 2008;108:310-317.

$\checkmark 6$ Weber KT: Aldosteronism revisited: perspectives on less well-recognized actions of aldosterone. J Lab Clin Med 2003;142:71-82.
7 Funder JW: Aldosterone, hypertension and heart failure: insights from clinical trials. $\mathrm{Hy}$ pertens Res 2010;33:872-875.

8 Xanthakis V, Vasan RS: Aldosterone and the risk of hypertension. Curr Hypertens Rep 2013;15:102-107.

$\checkmark 9$ Gekle M, Bretschneider M, Meinel S, Ruhs S, Grossmann C: Rapid mineralocorticoid receptor trafficking. Steroids 2014;81C:103108 
10 Hawkins UA, Gomez-Sanchez EP, GomezSanchez CM, Gomez-Sanchez CE: The ubiquitous mineralocorticoid receptor: clinical implications. Curr Hypertens Rep 2012;14: 573-580.

11 Martinerie L, Munier M, Le Menuet D, Meduri G, Viengchareun S, Lombes M: The mineralocorticoid signaling pathway throughout development: expression, regulation and pathophysiological implications. Biochimie 2013;95:148-157.

12 Fuller PJ, Yao Y, Yang J, Young MJ: Mechanisms of ligand specificity of the mineralocorticoid receptor. J Endocrinol 2012;213:15-24.

13 Odermatt A, Kratschmar DV: Tissue-specific modulation of mineralocorticoid receptor function by $11 \beta$-hydroxysteroid dehydrogenases: an overview. Mol Cell Endocrinol 2012; 350:168-186.

14 Dai LJ, Ritchie G, Kerstan D, Kang HS, Cole DE, Quamme GA: Magnesium transport in the renal distal convoluted tubule. Physiol Rev 2001;81:51-84.

15 Tomaschitz A, Ritz E, Pieske B, Rus-Machan J, Kienreich K, Verheyen N, Gaksch M, Grubler M, Fahrleitner-Pammer A, Mrak P, Toplak H, Kraigher-Krainer E, Marz W, Pilz $\mathrm{S}$ : Aldosterone and parathyroid hormone interactions as mediators of metabolic and cardiovascular disease. Metabolism 2014;63:2031.

16 Laski ME, Sabatini S: Metabolic alkalosis, bedside and bench. Semin Nephrol 2006;26: 404-421.

$\checkmark 17$ Levine DZ, Jacobson HR: The regulation of renal acid secretion: new observations from studies of distal nephron segments. Kidney Int 1986;29:1099-1109.

18 Wagner CA: Effect of mineralocorticoids on acid-base balance. Nephron Physiol 2014;128: 26-34.

19 Pelzl L, Pakladok T, Pathare G, Fakhri H, Michael D, Wagner CA, Paulmichl M, Lang F: DOCA sensitive pendrin expression in kidney, heart, lung and thyroid tissues. Cell Physiol Biochem 2012;30:1491-1501.

-20 Fu Y, Vallon V: Mineralocorticoid-induced sodium appetite and renal salt retention: evidence for common signaling and effector mechanisms. Nephron Physiol 2014;128: $8-16$.

-21 Murck H, Buettner M, Kircher T, Konrad C: Genetic, molecular and clinical determinants for the involvement of aldosterone and its receptors in major depression. Nephron Physiol 2014;128:17-25.

22 Shibata H, Itoh H: Mineralocorticoid receptor-associated hypertension and its organ damage: clinical relevance for resistant hypertension. Am J Hypertens 2012;25:514-523.

23 Wu J, Luft FC: Mineralocorticoid-receptor signalling in vascular smooth muscle. Nephrol Dial Transplant 2013;28:1360-1362.

24 Barrett KV, McCurley AT, Jaffe IZ: Direct contribution of vascular mineralocorticoid receptors to blood pressure regulation. Clin Exp Pharmacol Physiol 2013;40:902-909.
Koenig JB, Jaffe IZ: Direct role for smooth muscle cell mineralocorticoid receptors in vascular remodeling: novel mechanisms and clinical implications. Curr Hypertens Rep 2014; 16:427.

26 Lang F: Stiff endothelial cell syndrome in vascular inflammation and mineralocorticoid excess. Hypertension 2011;57:146-147.

-27 Oberleithner H, Ludwig T, Riethmuller C, Hillebrand U, Albermann L, Schafer C, Shahin V, Schillers H: Human endothelium: target for aldosterone. Hypertension 2004;43: 952-956.

28 Oberleithner $\mathrm{H}$ : Is the vascular endothelium under the control of aldosterone? Facts and hypothesis. Pflugers Arch 2007;454:187-193.

29 Oberleithner H, Kusche-Vihrog K, Schillers $\mathrm{H}$ : Endothelial cells as vascular salt sensors. Kidney Int 2010;77:490-494.

30 Sugiyama T, Yoshimoto T, Tsuchiya K, Gochou N, Hirono Y, Tateno T, Fukai N, Shichiri M, Hirata Y: Aldosterone induces angiotensin converting enzyme gene expression via a JAK2-dependent pathway in rat endothelial cells. Endocrinology 2005;146:3900-3906.

31 McCurley A, Pires PW, Bender SB, Aronovitz M, Zhao MJ, Metzger D, Chambon P, Hill MA, Dorrance AM, Mendelsohn ME, Jaffe IZ: Direct regulation of blood pressure by smooth muscle cell mineralocorticoid receptors. Nat Med 2012;18:1429-1433.

32 McGraw AP, McCurley A, Preston IR, Jaffe IZ: Mineralocorticoid receptors in vascular disease: connecting molecular pathways to clinical implications. Curr Atheroscler Rep 2013;15:340.

- 33 Briet M, Schiffrin EL: Vascular actions of aldosterone. J Vasc Res 2013;50:89-99.

34 Lacolley P, Challande P, Osborne-Pellegrin M, Regnault V: Genetics and pathophysiology of arterial stiffness. Cardiovasc Res 2009;81: 637-648.

35 Jaffe IZ, Tintut Y, Newfell BG, Demer LL, Mendelsohn ME: Mineralocorticoid receptor activation promotes vascular cell calcification. Arterioscler Thromb Vasc Biol 2007;27: 799-805.

36 Voelkl J, Alesutan I, Leibrock CB, Quintanilla-Martinez L, Kuhn V, Feger M, Mia S, Ahmed MS, Rosenblatt KP, Kuro OM, Lang F: Spironolactone ameliorates PIT1-dependent vascular osteoinduction in klotho-hypomorphic mice. J Clin Invest 2013;123:812822.

37 Lang F, Ritz E, Alesutan I, Voelkl J: Impact of aldosterone on osteoinductive signaling and vascular calcification. Nephron Physiol 2014; 128:40-45.

38 Alesutan I, Feger M, Pakladok T, Mia S, Ahmed MS, Voelkl J, Lang F: 25-Hydroxyvitamin $\mathrm{D}_{3} 1 \alpha$-hydroxylase-dependent stimulation of renal klotho expression by spironolactone. Kidney Blood Press Res 2013;37:475487.
9 Tang C, Pathare G, Michael D, Fajol A, Eichenmuller M, Lang F: Downregulation of Klotho expression by dehydration. Am J Physiol Renal Physiol 2011;301:F745-750.

-40 Artunc F, Amann K, Nasir O, Friedrich B, Sandulache D, Jahovic N, Risler T, Vallon V, Wulff P, Kuhl D, Lang F: Blunted DOCA/ high salt induced albuminuria and renal tubulointerstitial damage in gene-targeted mice lacking SGK1. J Mol Med (Berl) 2006; 84:737-746.

41 Azibani F, Fazal L, Chatziantoniou C, Samuel JL, Delcayre C: Aldosterone mediates cardiac fibrosis in the setting of hypertension. Curr Hypertens Rep 2013;15:395-400.

42 Bae EH, Kim IJ, Joo SY, Kim EY, Kim CS, Choi JS, Ma SK, Kim SH, Lee JU, Kim SW: Renoprotective effects of sildenafil in DOCAsalt hypertensive rats. Kidney Blood Press Res 2012;36:248-257.

43 Brown NJ: Contribution of aldosterone to cardiovascular and renal inflammation and fibrosis. Nat Rev Nephrol 2013;9:459-469.

44 Chen H, Sun F, Zhong X, Shao Y, Yoshimura A, Liu Y: Eplerenone-mediated aldosterone blockade prevents renal fibrosis by reducing renal inflammation, interstitial cell proliferation and oxidative stress. Kidney Blood Press Res 2013;37:557-566.

45 Fagart J, Huyet J, Pinon GM, Rochel M, Mayer C, Rafestin-Oblin ME: Crystal structure of a mutant mineralocorticoid receptor responsible for hypertension. Nat Struct Mol Biol 2005;12:554-555.

46 Fejes-Toth G, Naray-Fejes-Toth A: Early aldosterone-regulated genes in cardiomyocytes: clues to cardiac remodeling? Endocrinology 2007;148:1502-1510.

47 Lahmer T, Hermans R, Schmaderer C, Chang J, Stock K, Lutz J, Heemann U, Baumann M: Mineralocorticoid receptor antagonism and aldosterone synthesis inhibition do not improve glomerulosclerosis and renal interstitial fibrosis in a model of chronic kidney allograft injury. Kidney Blood Press Res 2012; 35:561-567.

48 Latouche C, Sainte-Marie Y, Steenman M, Castro Chaves P, Naray-Fejes-Toth A, FejesToth G, Farman N, Jaisser F: Molecular signature of mineralocorticoid receptor signaling in cardiomyocytes: from cultured cells to mouse heart. Endocrinology 2010;151:44674476.

-49 Lucisano S, Buemi M, Passantino A, Aloisi C, Cernaro V, Santoro D: New insights on the role of vitamin $\mathrm{D}$ in the progression of renal damage. Kidney Blood Press Res 2013;37: 667-678.

50 Makowka A, Olejniczak-Fortak M, Nowicki $\mathrm{M}$ : A comparison of the antihypertensive and anti-inflammatory effects of aliskiren and ramipril add-on therapy in peritoneal dialysis patients - a pilot open label study. Kidney Blood Press Res 2012;36:18-25. 
51 Okazaki A, Mori Y, Nakata M, Kimura T, Sonomura K, Sakoda C, Matsuoka E, Ishida M, Yamahara H, Kishimoto N, Nakagawa H, Matsubara H: Peritoneal mesothelial cells as a target of local aldosterone action: upregulation of connective tissue growth factor expression via serum- and glucocorticoid-inducible protein kinase 1. Kidney Blood Press Res 2009;32:151-160.

52 Tylicki L, Lizakowski S, Rutkowski P, Renke M, Sulikowska B, Heleniak Z, Donderski R, Bednarski R, Przybylska M, Manitius J, Rutkowski B: The enhanced renin-angiotensinaldosterone system pharmacological blockade - which is the best? Kidney Blood Press Res 2012;36:335-343.

-53 Vallon V, Wyatt AW, Klingel K, Huang DY, Hussain A, Berchtold S, Friedrich B, Grahammer F, Belaiba RS, Gorlach A, Wulff P, Daut J, Dalton ND, Ross J Jr, Flogel U, Schrader J, Osswald H, Kandolf R, Kuhl D, Lang F: SGK1-dependent cardiac CTGF formation and fibrosis following DOCA treatment. J Mol Med (Berl) 2006;84:396-404.

54 Yamahara H, Kishimoto N, Nakata M, Okazaki A, Kimura T, Sonomura K, Matsuoka E, Shiotsu Y, Adachi T, Matsubara H, Iwasaka T, Mori Y: Direct aldosterone action as a profibrotic factor via ROS-mediated SGK1 in peritoneal fibroblasts. Kidney Blood Press Res 2009;32:185-193.

55 Young M, Funder JW: Aldosterone and the heart. Trends Endocrinol Metab 2000;11: 224-226.

56 Young M, Funder J: Mineralocorticoid action and sodium-hydrogen exchange: studies in experimental cardiac fibrosis. Endocrinology 2003;144:3848-3851.

57 Artunc F, Lang F: Mineralocorticoid stimulation of tissue fibrosis. Nephron Physiol, 2014.

-58 Bienvenu LA, Reichelt ME, Delbridge LM, Young MJ: Mineralocorticoid receptors and the heart, multiple cell types and multiple mechanisms: a focus on the cardiomyocyte. Clin Sci (Lond) 2013;125:409-421.

-59 Galuppo P, Bauersachs J: Mineralocorticoid receptor activation in myocardial infarction and failure: recent advances. Eur J Clin Invest 2012;42:1112-1120.

-60 Bender SB, McGraw AP, Jaffe IZ, Sowers JR: Mineralocorticoid receptor-mediated vascular insulin resistance: an early contributor to diabetes-related vascular disease? Diabetes 2013;62:313-319.

-61 Feraco A, Armani A, Mammi C, Fabbri A, Rosano GM, Caprio M: Role of mineralocorticoid receptor and renin-angiotensin-aldosterone system in adipocyte dysfunction and obesity. J Steroid Biochem Mol Biol 2013;137: 99-106.

-62 Garg R, Adler GK: Role of mineralocorticoid receptor in insulin resistance. Curr Opin Endocrinol Diabetes Obes 2012;19:168-175.
63 Ronconi V, Turchi F, Appolloni G, di Tizio V, Boscaro M, Giacchetti G: Aldosterone, mineralocorticoid receptor and the metabolic syndrome: role of the mineralocorticoid receptor antagonists. Curr Vasc Pharmacol 2012;10:238-246.

64 Berardelli R, Karamouzis I, D’Angelo V, Zichi C, Fussotto B, Giordano R, Ghigo E, Arvat E: Role of mineralocorticoid receptors on the hypothalamus-pituitary-adrenal axis in humans. Endocrine 2013;43:51-58.

65 De Kloet ER, Joels M, Holsboer F: Stress and the brain: from adaptation to disease. Nat Rev Neurosci 2005;6:463-475.

66 Deutsch SI, Mastropaolo J: Discriminative stimulus properties of midazolam are shared by a GABA-receptor positive steroid. Pharmacol Biochem Behav 1993;46:963-965.

67 Rupprecht R, Holsboer F: Neuroactive steroids: mechanisms of action and neuropsychopharmacological perspectives. Trends Neurosci 1999;22:410-416.

68 Liu G, Liu G, Alzoubi K, Umbach AT, Pelzl L, Borst O, Gawaz M, Lang F: Upregulation of store operated Ca channel Orail, stimulation of $\mathrm{Ca}^{2+}$ entry and triggering of cell membrane scrambling in platelets by mineralocorticoid DOCA. Kidney Blood Press Res 2014;38:2130.

69 Oh-hashi S, Takata M, Ueno H, Tomoda F, Yasumoto K, Iida H, Sasayama S: Cytosolic free calcium concentration in platelets in patients with renovascular hypertension and primary aldosteronism. J Hum Hypertens 1992;6:71-74.

70 Braun A, Vogtle T, Varga-Szabo D, Nieswandt B: STIM and Orai in hemostasis and thrombosis. Front Biosci (Landmark Ed) 2011;16: 2144-2160.

71 Parekh AB: Store-operated CRAC channels: function in health and disease. Nat Rev Drug Discov 2010;9:399-410.

72 Bergmeier W, Stefanini L: Novel molecules in calcium signaling in platelets. J Thromb Haemost 2009; (suppl 1):187-190.

73 Braun A, Varga-Szabo D, Kleinschnitz C, Pleines I, Bender M, Austinat M, Bosl M, Stoll G, Nieswandt B: Orail (CRACM1) is the platelet SOC channel and essential for pathological thrombus formation. Blood 2009;113: 2056-2063.

74 Varga-Szabo D, Braun A, Nieswandt B: Calcium signaling in platelets. J Thromb Haemost 2009;7:1057-1066.

75 Bearer EL, Prakash JM, Li Z: Actin dynamics in platelets. Int Rev Cytol 2002;217:137-182.

76 Borst O, Munzer P, Gatidis S, Schmidt EM, Schonberger T, Schmid E, Towhid ST, Stellos K, Seizer P, May AE, Lang F, Gawaz M: The inflammatory chemokine CXC motif ligand 16 triggers platelet activation and adhesion via CXC motif receptor 6-dependent phosphatidylinositide 3-kinase/Akt signaling. Circ Res 2012;111:1297-1307.
77 Harper MT, Poole AW: Store-operated calcium entry and non-capacitative calcium entry have distinct roles in thrombin-induced calcium signalling in human platelets. Cell Calcium 2011;50:351-358.

78 Mahaut-Smith MP: A role for platelet TRPC channels in the $\mathrm{Ca}^{2+}$ response that induces procoagulant activity. Sci Signal 2013;6:pe23.

79 Mushtaq M, Nam TS, Kim UH: Critical role for CD38-mediated $\mathrm{Ca}^{2+}$ signaling in thrombin-induced procoagulant activity of mouse platelets and hemostasis. J Biol Chem 2011; 286:12952-12958.

80 Varga-Szabo D, Braun A, Nieswandt B: STIM and Orai in platelet function. Cell Calcium 2011;50:270-278.

81 Wolfs JL, Comfurius P, Rasmussen JT, Keuren JF, Lindhout T, Zwaal RF, Bevers EM: Activated scramblase and inhibited aminophospholipid translocase cause phosphatidylserine exposure in a distinct platelet fraction. Cell Mol Life Sci 2005;62:1514-1525.

82 Borst $\mathrm{O}$, Schmidt EM, Munzer P, Schonberger T, Towhid ST, Elvers M, Leibrock C, Schmid E, Eylenstein A, Kuhl D, May AE, Gawaz M, Lang F: The serum- and glucocorticoid-inducible kinase 1 (SGK1) influences platelet calcium signaling and function by regulation of Orail expression in megakaryocytes. Blood 2012;119:251-261.

83 Schmidt EM, Kraemer BF, Borst O, Munzer P, Schonberger T, Schmidt C, Leibrock C, Towhid ST, Seizer P, Kuhl D, Stournaras C, Lindemann S, Gawaz M, Lang F: SGK1 sensitivity of platelet migration. Cell Physiol Biochem 2012;30:259-268.

84 Lang F, Bohmer C, Palmada M, Seebohm G, Strutz-Seebohm N, Vallon V: (Patho)physiological significance of the serum- and glucocorticoid-inducible kinase isoforms. Physiol Rev 2006;86:1151-1178.

85 Schmid E, Bhandaru M, Nurbaeva MK, Yang W, Szteyn K, Russo A, Leibrock C, Tyan L, Pearce D, Shumilina E, Lang F: SGK3 regulates $\mathrm{Ca}^{2+}$ entry and migration of dendritic cells. Cell Physiol Biochem. 2012;30:14231435.

86 Lagrange J, Li Z, Fassot C, Bourhim M, Louis H, Nguyen Dinh Cat A, Parlakian A, Wahl D, Lacolley P, Jaisser F, Regnault V: Endothelial mineralocorticoid receptor activation enhances endothelial protein $\mathrm{C}$ receptor and decreases vascular thrombosis in mice. FASEB J 2014;10.1096/fj.13-238188.

87 Firsov D: Revisiting sodium and water reabsorption with functional genomics tools. Curr Opin Nephrol Hypertens 2004;13:59-65.

88 Kellner M, Peiter A, Hafner M, Feuring M, Christ M, Wehling M, Falkenstein E, Losel R: Early aldosterone up-regulated genes: new pathways for renal disease? Kidney Int 2003; 64:1199-1207. 
89 Sekizawa N, Yoshimoto T, Hayakawa E, Suzuki N, Sugiyama T, Hirata Y: Transcriptome analysis of aldosterone-regulated genes in human vascular endothelial cell lines stably expressing mineralocorticoid receptor. Mol Cell Endocrinol 2011;341:7888.

90 Baker ME, Funder JW, Kattoula SR: Evolution of hormone selectivity in glucocorticoid and mineralocorticoid receptors. J Steroid Biochem Mol Biol 2013;137:57-70.

91 Lang F, Stournaras C: Serum and glucocor- 105 ticoid inducible kinase, metabolic syndrome, inflammation, and tumor growth. Hormones (Athens) 2013;12:160-171.

92 Lang F, Voelkl J: Therapeutic potential of serum and glucocorticoid inducible kinase inhibition. Expert Opin Investig Drugs 2013;22:701-714.

$\$ 93$ Ennis IL, Aiello EA, Cingolani HE, Perez NG: The autocrine/paracrine loop after myocardial stretch: mineralocorticoid receptor activation. Curr Cardiol Rev 2013;9: 230-240.

94 Voelkl J, Lin Y, Alesutan I, Ahmed MS, Pasham V, Mia S, Gu S, Feger M, Saxena A, Metzler B, Kuhl D, Pichler BJ, Lang F: Sgk1 sensitivity of $\mathrm{Na}^{+} / \mathrm{H}^{+}$exchanger activity and cardiac remodeling following pressure overload. Basic Res Cardiol 2012;107:236.

95 Voelkl J, Pasham V, Ahmed MS, Walker B, Szteyn K, Kuhl D, Metzler B, Alesutan I, Lang F: Sgk1-dependent stimulation of car$\operatorname{diac} \mathrm{Na}^{+} / \mathrm{H}^{+}$exchanger Nhe1 by dexamethasone. Cell Physiol Biochem 2013;32:25-38.

96 Nagase M, Fujita T: Role of Rac1-mineralocorticoid-receptor signalling in renal and cardiac disease. Nat Rev Nephrol 2013;9: 86-98.

-97 Christ M, Sippel K, Eisen C, Wehling M: Non-classical receptors for aldosterone in plasma membranes from pig kidneys. Mol Cell Endocrinol 1994;99:R31-R34.

$\$ 98$ Mohammed SF, Ohtani T, Korinek J, Lam CS, Larsen K, Simari RD, Valencik ML, Burnett JC Jr, Redfield MM: Mineralocorticoid accelerates transition to heart failure with preserved ejection fraction via 'nongenomic effects'. Circulation 2010;122:370-378.

-99 Pietranera L, Saravia FE, McEwen BS, Lucas LL, Johnson AK, De Nicola AF: Changes in Fos expression in various brain regions during deoxycorticosterone acetate treatment: relation to salt appetite, vasopressin mRNA and the mineralocorticoid receptor. Neuroendocrinology 2001;74:396-406.

100 Quinn S, Harvey BJ, Thomas W: Rapid aldosterone actions on epithelial sodium channel trafficking and cell proliferation. Steroids 2014;81C:43-48.

101 Roy JW, Hill E, Ruan YC, Vedovelli L, Paunescu TG, Brown D, Breton S: Circulating aldosterone induces the apical accumulation of the proton pumping V-ATPase and increases proton secretion in clear cells in the caput epididymis. Am J Physiol Cell Physiol 2013;305:C436-C446.
102 Wehling M, Christ M, Theisen K: Membrane receptors for aldosterone: a novel pathway for mineralocorticoid action. Am J Physiol 1992;263:E974-E979.

103 Wendler A, Albrecht C, Wehling M: Nongenomic actions of aldosterone and progesterone revisited. Steroids 2012;77:1002-1006.

104 Williams JS: Evolving research in nongenomic actions of aldosterone. Curr Opin Endocrinol Diabetes Obes 2013;20:198203.

05 Liu SL, Schmuck S, Chorazcyzewski JZ, Gros R, Feldman RD: Aldosterone regulates vascular reactivity: short-term effects mediated by phosphatidylinositol 3-kinase-dependent nitric oxide synthase activation. Circulation 2003;108:2400-2406.

106 Mutoh A, Isshiki M, Fujita T: Aldosterone enhances ligand-stimulated nitric oxide production in endothelial cells. Hypertens Res 2008;31:1811-1820.

107 Lindemann S, Tolley ND, Eyre JR, Kraiss LW, Mahoney TM, Weyrich AS: Integrins regulate the intracellular distribution of eukaryotic initiation factor $4 \mathrm{E}$ in platelets. A checkpoint for translational control. J Biol Chem 2001;276:33947-33951.

108 Rosenwald IB, Pechet L, Han A, Lu L, Pihan G, Woda B, Chen JJ, Szymanski I: Expression of translation initiation factors elF-4E and elF- $2 \alpha$ and a potential physiologic role of continuous protein synthesis in human platelets. Thromb Haemost 2001;85:142151.

109 Weyrich AS, Dixon DA, Pabla R, Elstad MR, McIntyre TM, Prescott SM, Zimmerman GA: Signal-dependent translation of a regulatory protein, $\mathrm{Bcl}-3$, in activated human platelets. Proc Natl Acad Sci USA 1998;95: 5556-5561.

110 Munzer P, Tolios A, Pelzl L, Schmid E, Schmidt EM, Walker B, Frohlich H, Borst O, Gawaz M, Lang F: Thrombin-sensitive expression of the store operated $\mathrm{Ca}^{2+}$ channel Orail in platelets. Biochem Biophys Res Commun 2013;436:25-30.

111 Dabrowski R, Szwed H: Antiarrhythmic potential of aldosterone antagonists in atrial fibrillation. Cardiol J 2012;19:223-229.

112 Lee TM, Chung TH, Lin SZ, Chang NC: Endothelin receptor blockade ameliorates renal injury by inhibition of RhoA/Rho-kinase signalling in deoxycorticosterone acetate-salt hypertensive rats. J Hypertens 2014;32:795-805.

113 Ma TK, Szeto CC: Mineralocorticoid receptor antagonist for renal protection. Ren Fail 2012;34:810-817.

114 Namsolleck P, Unger T: Aldosterone synthase inhibitors in cardiovascular and renal diseases. Nephrol Dial Transplant 2014; 29(suppl 1):i62-i68.

115 Nguyen Dinh Cat A, Jaisser F: Extrarenal effects of aldosterone. Curr Opin Nephrol Hypertens 2012;21:147-156.
16 Zannad F, Gattis Stough W, Rossignol P, Bauersachs J, McMurray JJ, Swedberg K, Struthers AD, Voors AA, Ruilope LM, Bakris GL, O'Connor CM, Gheorghiade M, Mentz RJ, Cohen-Solal A, Maggioni AP, Beygui F, Filippatos GS, Massy ZA, Pathak A, Pina IL, Sabbah HN, Sica DA, Tavazzi L, Pitt B: Mineralocorticoid receptor antagonists for heart failure with reduced ejection fraction: integrating evidence into clinical practice. Eur Heart J 2012;33:2782-2795.

117 McCurley A, McGraw A, Pruthi D, Jaffe IZ: Smooth muscle cell mineralocorticoid receptors: role in vascular function and contribution to cardiovascular disease. Pflugers Arch 2013;465:1661-1670.

118 Ueda K, Nagase M: Mineralocorticoid receptor activation as an etiological factor in kidney diseases. Clin Exp Nephrol 2014;18: 16-23.

119 Gawaz M: Role of platelets in coronary thrombosis and reperfusion of ischemic myocardium. Cardiovasc Res 2004;61:498511.

120 Bigalke B, Stellos K, Geisler T, Kremmer E, Seizer P, May AE, Lindemann S, Melms A, Luft A, Gawaz M: Expression of platelet glycoprotein VI is associated with transient ischemic attack and stroke. Eur J Neurol 2010;17:111-117.

121 Fourkiotis VG, Hanslik G, Hanusch F, Lepenies J, Quinkler M: Aldosterone and the kidney. Horm Metab Res 2012;44:194-201.

122 Allen LA, Shetterly SM, Peterson PN, Gurwitz JH, Smith DH, Brand DW, Fairclough DL, Rumsfeld JS, Masoudi FA, Magid DJ: Guideline concordance of testing for hyperkalemia and kidney dysfunction during initiation of mineralocorticoid receptor antagonist therapy in patients with heart failure. Circ Heart Fail 2014;7:43-50.

123 Baker WL, White WB: Safety of mineralocorticoid receptor antagonists in patients receiving hemodialysis. Ann Pharmacother 2012;46:889-894

124 Bomback AS, Klemmer PJ: Mineralocorticoid receptor blockade in chronic kidney disease. Blood Purif 2012;33:119-124.

125 Collin M, Niemann F, Jaisser F: Mineralocorticoid receptor modulators: a patent review (2007-2012). Expert Opin Ther Pat 2014;24:177-183.

126 Funder JW: Mineralocorticoid receptor antagonists: emerging roles in cardiovascular medicine. Integr Blood Press Control 2013; 6:129-138.

127 Hammer F, Krane V, Stork S, Roser C, Hofmann K, Pollak N, Allolio B, Wanner C: Rationale and design of the Mineralocorticoid Receptor Antagonists in End-Stage Renal Disease Study (MiREnDa). Nephrol Dial Transplant 2014;29:400-405.

128 Markowitz M, Messineo F, Coplan NL: Aldosterone receptor antagonists in cardiovascular disease: a review of the recent literature and insight into potential future indications. Clin Cardiol 2012;35:605-609. 
129 Mavrakanas TA, Gariani K, Martin PY: Mineralocorticoid receptor blockade in addition to angiotensin converting enzyme inhibitor or angiotensin II receptor blocker treatment. An emerging paradigm in diabetic nephropathy: a systematic review. Eur J Intern Med 2014;25:173-176.

130 Piotrowski DW: Mineralocorticoid receptor antagonists for the treatment of hypertension and diabetic nephropathy. J Med Chem 2012;55:7957-7966.

131 Pitt B: The role of mineralocorticoid receptor antagonists in patients with American College of Cardiology/American Heart Association stage B heart failure. Heart Fail Clin 2012;8:247-253.

132 Richards AM: Mineralocorticoid receptor antagonists for heart failure. Expert Opin Pharmacother 2011;12:2801-2815.
133 Roscioni SS, de Zeeuw D, Bakker SJ, Lambers Heerspink HJ: Management of hyperkalaemia consequent to mineralocorticoidreceptor antagonist therapy. Nat Rev Nephrol 2012;8:691-699.

134 Sato A: Mineralocorticoid receptor antagonists: their use and differentiation in Japan. Hypertens Res 2013;36:185-190.

135 Seawell MR, Al Darazi F, Farah V, Ramanathan KB, Newman KP, Bhattacharya SK, Weber KT: Mineralocorticoid receptor antagonism confers cardioprotection in heart failure. Curr Heart Fail Rep 2013;10:36-45.

136 Shavit L, Lifschitz MD, Epstein M: Aldosterone blockade and the mineralocorticoid receptor in the management of chronic kidney disease: current concepts and emerging treatment paradigms. Kidney Int 2012;81: 955-968.
37 Talatinian A, Chow SL, Heywood JT: Expanding role of mineralocorticoid receptor antagonists in the treatment of heart failure. Pharmacotherapy 2012;32:827-837.

138 Van den Berg TN, Rongen GA, Frohlich GM, Deinum J, Hausenloy DJ, Riksen NP. The cardioprotective effects of mineralocorticoid receptor antagonists. Pharmacol Ther 2014;142:72-87.

39 Young MJ: Targeting the mineralocorticoid receptor in cardiovascular disease. Expert Opin Ther Targets 2013;17:321-331.

140 Zwadlo C, Bauersachs J: Mineralocorticoid receptor antagonists for therapy of coronary artery disease and related complications. Curr Opin Pharmacol 2013;13:280-286. 